\title{
Company Culture Audit to Improve Development Team's Collaboration, Communication, and Cooperation
}

\author{
Emilie Gould ${ }^{1}$ and Aaron Marcus ${ }^{2}$ \\ ${ }^{1}$ SUNY Albany, Albany, NY \\ egouldealbany . edu \\ ${ }^{2}$ Aaron Marcus and Associates, Inc., 1196 Euclid Avenue, \\ Suite 1F, Berkeley, CA, 94708 USA \\ Aaron. Marcus@AMandA.com
}

\begin{abstract}
Multinational companies worldwide seek to improve product/service development-teams operating in different countries. One of their objectives is to improve collaboration, communication, and cooperation among teams. Aaron Marcus and Associates, Inc. (AM+A) recommended countries and locations in which to undertake research into teamwork within a company, accounting for cultural differences and approaches to teamwork/leadership
\end{abstract}

Keywords: Business, collaboration, communication, cooperation, culture, design, development, software, management, user interface, user experience.

\section{Introduction}

A California client planned a company-wide study of collaboration and asked $\mathrm{AM}+\mathrm{A}$ to recommend four sites from a list of 15 countries in six work regions. The client had already chosen a specific site in the US because, as the client's corporate headquarters, it needed to be able to work with sites throughout the world. A key assumption of our recommendations was that the other sites should represent the greatest diversity relative to the headquarters site in terms of culture, along with the greatest opportunities for innovation in collaboration.

Initially, we used two sets of criteria to identify appropriate sites. The first set of criteria were based on traditional measures of culture that are applicable to teamwork. The second set dealt with technological innovation and globalization. After an informational interview with the project sponsors, additional criteria were discussed and additional data on the client employee demographics were made available. As a result, an additional criterion was added in our data summary: gender balance.

\section{Recommendations}

$\mathrm{AM}+\mathrm{A}$ recommended that the four cities to be studied along with the US corporate headquarters site should be the following: 


\begin{tabular}{|l|l|l|}
\hline Amsterdam & Netherlands & $\begin{array}{l}\text { Representative of North European, gender-balanced, } \\
\text { egalitarian styles of collaboration }\end{array}$ \\
\hline Bangalore & India & $\begin{array}{l}\text { Representative of both S. Asian mentor-based col- } \\
\text { laboration and new modes of globalization }\end{array}$ \\
\hline Dubai & $\begin{array}{l}\text { United Arab } \\
\text { Emirates }\end{array}$ & $\begin{array}{l}\text { Representative of high power distance and new } \\
\text { modes associated with globalization }\end{array}$ \\
\hline Tokyo & Japan & $\begin{array}{l}\text { Representative of East Asian, Confucian-based } \\
\text { collaboration styles (high power distance and strong } \\
\text { work group orientation) }\end{array}$ \\
\hline
\end{tabular}

Alternative cities included:

- Feltham for Amsterdam: Because the US and UK share many cultural values, Amsterdam was chosen as representative of more egalitarian, gender-neutral styles.

- Singapore for Dubai: Dubai currently leads the world in population growth as the UAE moves from oil to a new economy based on trade, finance, and information. Singapore has already successfully refocused its economy on the same elements through a much more regulated and state-controlled process representative of traditional Chinese values (strong leadership, high power distance, and collectivism).

- Seoul for Tokyo: Like Tokyo, Seoul uses a strongly Confucian style of leadership that promotes group coordination and tends to limit individual action.

If circumstances allowed further cities, Shanghai could be researched. It was not included in the initial list due to the AM+A's understanding that this project was seeking out the most diverse (orthogonal) range of collaboration practices within the client's international sites. We believe the spectacular increase in Chinese university training based on Western models has diluted the traditional Confucian orientation of young employees. By contrast, Japanese (and Korean and Singaporean) employees are expected to be more conservative in their communication style. In all cases, $\mathrm{AM}+\mathrm{A}$ recommended specific locations with at least 200 employees to be researched so that the data collected would have strong statistical validity.

\subsection{Data Visualization of the Recommendations}

Using data supplied by the client and data that $\mathrm{AM}+\mathrm{A}$ located, $\mathrm{AM}+\mathrm{A}$ prepared a summary "visual table" comparing the international cities that $\mathrm{AM}+\mathrm{A}$ recommended in comparison to the headquarters city. The values show the headquarters city presented with a value set at 1.0, and other values based on the data sources cited immediately below. The sequence emphasizes the cities that the client subsequently selected: Amsterdam, Bangalore, Singapore, and Tokyo, with data for Dubai and Shanghai shown additionally. The black rectangles show the maximum values for the criteria, and the white rectangles show the minimum values for the criteria.

The cities recommended provide strongly different culture attributes, which should make for effective, valuable studies of client corporate culture and differences and/or similarities in teamwork, which is the objective of the client's research. The sources of the data follow the table: 


\begin{tabular}{|c|c|c|c|c|c|c|c|}
\hline \multicolumn{8}{|c|}{ Cross-Cultural Comparisons with CA City } \\
\hline & $\begin{array}{c}\text { ach } \\
\text { wish }\end{array}$ & novetum & smonom & simperoner & $\begin{array}{c}\text { Torke } \\
\text { sime }\end{array}$ & $\begin{array}{l}\text { Dous } \\
\text { wae }\end{array}$ & 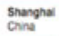 \\
\hline 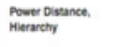 & 1.0 & 0.95 & 1.93 & 1.85 & 1.35 & 2.00 & 1.22 \\
\hline indiviautum & 1.0 & 0.88 & 0.53 & 0.22 & 0.51 & 0.42 & 0.94 \\
\hline 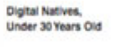 & 1.0 & 1.07 & 3.60 & 0.40 & 1.13 & 0.73 & 2.00 \\
\hline 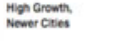 & 1.0 & 0.43 & 2.18 & 1.03 & 0.17 & 2.70 & 1.94 \\
\hline 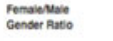 & 1.0 & 0.90 & 0.58 & 1.10 & 0.61 & 0.42 & 0.81 \\
\hline
\end{tabular}

- Power Distance: With the exception of Shanghai, this data is drawn from the raw scores comparing 53 countries and national regions by Hofstede (1997). Due to his dependence on IBM data, Hofstede did not include China in his original study. As a result, the score for China is drawn from Schwartz's comparison of 39 cultural groups (1994) for Hierarchy, normalized from a 9-point scale in ratio to the US.

- Individualism: As with Power Distance, all scores for individualism are taken from Hofstede (1997) with the exception of Shanghai. That score is taken from Schwartz's score for Conservatism, reversed, normalized, and cross-validated against his scores for Egalitarian Commitment, Affective Autonomy, and Intellectual Autonomy.

- Digital Nativity: This variable, defined as the client employees 30 and younger, is taken from employee demographic data.

- High Growth/ New Cities: This data is taken Urban agglomerations: Average annual rate of change (\%), World urbanization prospects: The 2007 revision population database, available online from the United Nations Population Division (esa.un.org/unup).

- Female/Male Gender Ratio: Variable taken from client employee demographic data.

\section{Analytical Criteria}

\subsection{Traditional Measures of Culture}

Since the early 1980s, a large number of variables have been identified from factor analysis to explain differences between national and regional cultures. Some of these traditional measures include the following: 


\begin{tabular}{|c|c|}
\hline $\begin{array}{l}\text { Hofstede's (1997) work } \\
\text { dimensions (inc. Hofstede } \\
\text { and Bond, 1988): }\end{array}$ & $\begin{array}{l}\text { - } \text { Power distance } \\
\text { - Individualism } v s . \text { collectivism } \\
\text { - } \quad \text { Long-term time-orientation ( Confucian values) }\end{array}$ \\
\hline $\begin{array}{l}\text { Trompenaars and } \\
\text { Hampden-Turner's (1998) } \\
\text { cultural dimensions: }\end{array}$ & $\begin{array}{l}\text { - Universalism } v s . \text { particularism } \\
\text { - Communitarianism } v s \text {. individualism } \\
\text { - Neutral } v s . \text { emotional expression }(\sim \text { use of reason } \\
\text { or feelings in relationships) } \\
\text { - Diffuse } v s . \text { specific range of involvement } \\
\text { - Achievement } v s . \text { ascription }\end{array}$ \\
\hline $\begin{array}{l}\text { Triandis' (2000) cultural } \\
\text { syndromes: }\end{array}$ & - Individualism \\
\hline $\begin{array}{l}\text { Markus and Kitayama's } \\
\text { (1991) notion of self- } \\
\text { concept: }\end{array}$ & $\begin{array}{l}\text { - Independent self-concept } \\
\text { - Interdependent self-concept }\end{array}$ \\
\hline $\begin{array}{l}\text { Schwartz's (1999) cultural } \\
\text { dimensions: }\end{array}$ & $\begin{array}{l}\text { - } \text { Conservatism } \\
\text { - Affective autonomy } \\
\text { - Intellectual autonomy } \\
\text { - Hierarchy } \\
\text { - Egalitarian Commitment } \\
\text { - Mastery } \\
\text { - Harmony }\end{array}$ \\
\hline
\end{tabular}

Despite the large number of concepts, many overlap. (Different researchers factor analyzed different data sets, which led to divergent results.) In addition, the concepts defined by Hofstede, Trompenaars and Hampden-Turner, and Triandis are ranged along a single continuum from high to low or most to least (e.g., power distance), while those measured by Markus and Kitayama and by Schwartz allow for greater diversity of behavior. According to Markus and Kitayama, individuals can hold independent and interdependent types of self-concept at the same time, but Hofstede theorized that people were either individualists or collectivists. (Note for comparison that Marcus and Baumgartner analyzed nine culture models by 11 authors, which elicited 29 dimensions that were rated by approximately 60 experts world-wide. From this set five "top" or most widely recommended dimensions emerged: context, technological development, uncertainty avoidance, and time perception. Data by country do not exist for all of these dimensions; they were not used for this paper.)

These traditional culture concepts are often associated with specific types of teamwork. In particular, Hofstede identified three major clusters of countries on the basis of ratings for power distance and individualism:

- High power distance/ collectivist: Mexico, China [Hong Kong], Singapore

- High power distance/ individualist: France

- Low power distance/ individualist: US, United Kingdom, Netherlands

People in collectivist countries with high power-distance (respect for authority) tend to be very dependent on their in-groups and rely on strong leaders who exercise moral authority. In addition, they may avoid direct confrontation (although they can engineer situations that let them apply rules to justify refusal). It is important to note 
that there are many historical variations of these values. India, with its tradition of close cooperation and mentorship between experienced and novice group members, is quite different from Tokyo, where managers are more separate from subordinates.

People in individualistic countries with high power-distance often develop bureaucratic systems that allow them to reconcile personal independence with absolute authority and centralized power. By contrast to collectivist countries, they may be more confrontational. People in individualistic countries with low power distance tend to work in loose groups and to treat others as peers; their allegiance to their in-groups is relatively weak so they find it easier to work with new people and outsiders. However, even within this cluster, there are historical patterns. Scandinavia is considered more egalitarian and "feminine"; work roles show less gender bias and groups look to achieve consensus.

There is much "surface validity" in Hofstede's categories, and he has been used in many studies of international business. However, when using Hofstede as a guide to study collaboration, it is important to remember that his data were collected from IBM in the late 1970s and early 1980s. Much has changed in global business since then, and much has changed in terms of the technologies and corporate strategies mandating teamwork. Hofstede was challenged by Michael Bond to develop a better measure for Asian countries. The result was a study based on Chinese cultural values, which looked at long-term vs. short-term orientation. As might be expected, China was ranked first of 23 countries, Japan fourth, and the US and the UK seventeenth and eighteenth. Several other client country sites ranked in between, with Brazil sixth, India seventh, Singapore ninth, and the Netherlands tenth. Trompenaars and Hampden-Turner's data are more recent (mid-1980s to late 1990s). Many of their culture concepts overlap with Hofstede's; others deal with notions of social systems first defined by Talcott Parsons in 1951 that are applicable to teamwork:

- Universalists use rules that apply to everyone and rely on procedural equity; particularists see social situations as more complex and tend to apply different rules to different types of people.

- Communitarians - like collectivists - place the needs and objectives of their group memberships ahead of their personal needs; individualists place their own needs first.

- People who display neutral affect tend to use reason as a basis for developing relationships; people who display a more emotional affect are more open about their feelings and expect emotional responses.

- People who have a specific range of involvement tend to view different business and personal contexts as separate from one another. They may recognize the authority of a manager at work but treat that manager as an equal when encountered at the mall. People who have a diffuse range of involvement with their work do not separate these contexts - a manager whose authority they recognize at work will retain that authority when met in a different situation.

Achievement and ascription refer to two methods used to assign group status and leadership. Status based on achievement is earned through an individual's personal accomplishments, especially work-related success. Status based on ascription is due 
to an individual's titles, gender, age, class, or education. Trompenaars and HampdenTurner analyzed a somewhat larger group of countries than Hofstede but did not always measure the same group of countries for each culture concept. Using Trompenaars and Hampden-Turner's categories, the client's work sites were classified. Using these culture categories along with Hofstede's work dimensions began to show new differences between apparently similar countries like the Netherlands and UK, and Japan and China

A third culture theorist, Harry Triandis, believes individualism is the most important of all cultural dimensions for explaining behavior. However, he notes that this factor can be modified by a wide range of cultural "syndromes," like social complexity, tightness (ethnic homogeneity vs. heterogeneity), and hierarchy. Cultures that are less complex or highly homogeneous tend to be collectivist; most people will display more conformity and suppress individual expression. However, from our work with Japanese students and employees, it is important to remember that people in tight or collectivist societies continue to think of themselves as highly individualist; they just choose to put group interests first

Markus and Kitayama also support this notion of duality. They found that the cultural dimension labeled individualism vs. collectivism was too simplistic and unable to explain real-world behavior. As a result, they redefined the phenomena as two mutually-coexisting concepts: Independent Self-concept and Interdependent Selfconcept. Their new variables better explain why American individualists give so broadly to charity while Malaysian collectivists do not. Strong membership in ingroups and an interdependent self-concept may prevent support for others in so-called out-groups. By contrast, people with an independent self-concept have a weak alliance to their in-groups and can see people in out-groups as being individuals just like them. These two types of self-concept may be important when looking at matrix management systems and the use of temporary work groups: in some cultures, longerterm groups may be more effective.

Finally, a last set of culture variables dealing with power and individualism was developed by Shalom Schwartz. His research was conducted in the late 1980s to mid1990s; his values can stand alone but are also correlated. Conservativism is generally opposed to Intellectual and Affective Autonomy, Hierarchy to Egalitarian Commitment, and Mastery to Harmony. Conservatism (plus Hierarchy, and Mastery) roughly equates to Collectivism while Intellectual and Affective Autonomy and Egalitarian Commitment equate to Individualism. Schwartz's use of the term harmony refers to respect for the natural world, not group harmony. Thus, his values tend to highlight differences between countries like the US and China that focus on mastery for economic growth and areas like northern Europe seeking stable growth to preserve the environment. Schwartz also collected data from many countries and has tables listing values for his variables. Although he does not list rankings for the UK, UAE, Russian Federation, Saudi Arabia, or India, he does rank the rest of the client sites. Schwartz (1999) made some clear predictions about relationships between his cultural values and specific work behaviors in the following table: 


\begin{tabular}{|c|c|c|}
\hline \multicolumn{3}{|c|}{$\begin{array}{l}\text { Hypothesized Compatibility and Conflict } \\
\text { of Culture Value Emphases with Dimensions of Work }\end{array}$} \\
\hline \multirow[b]{2}{*}{ Dimensions of Work } & \multicolumn{2}{|c|}{ Culture Value Emphases } \\
\hline & Compatible & Conflicting \\
\hline $\begin{array}{l}\text { Work Centrality: Contrasted with } \\
\text { leisure, community, family, } \\
\text { religion }\end{array}$ & $\begin{array}{l}\text { Mastery } \\
\text { Hierarchy }\end{array}$ & $\begin{array}{l}\text { Affective Autonomy } \\
\text { Egalitarianism } \\
\text { Harmony } \\
\text { Conservatism }\end{array}$ \\
\hline $\begin{array}{l}\text { Societal Norms re Working: } \\
\text { Entitlement } v \text { s. Obligation }\end{array}$ & $\begin{array}{l}\text { Egalitarianism } \\
\text { Intellectual Autonomy }\end{array}$ & $\begin{array}{l}\text { Conservatism } \\
\text { Hierarchy }\end{array}$ \\
\hline Work Values: Power & $\begin{array}{l}\text { Hierarchy } \\
\text { Mastery }\end{array}$ & $\begin{array}{l}\text { Harmony } \\
\text { Egalitarianism }\end{array}$ \\
\hline $\begin{array}{l}\text { Work Values: Intrinsic (personal } \\
\text { growth and creativity) }\end{array}$ & $\begin{array}{l}\text { Intellectual Autonomy } \\
\text { Affective Autonomy }\end{array}$ & Conservatism \\
\hline $\begin{array}{l}\text { Work Values: Extrinsic (monetary } \\
\text { rewards) }\end{array}$ & $\begin{array}{l}\text { Conservatism } \\
\text { Hierarchy }\end{array}$ & Intellectual Autonomy \\
\hline Work Values: Social & $\begin{array}{l}\text { Egalitarianism } \\
\text { Harmony }\end{array}$ & $\begin{array}{l}\text { Hierarchy } \\
\text { Mastery }\end{array}$ \\
\hline
\end{tabular}

This table suggests that Asian countries and northern European countries should be very different in terms of work centrality. In addition, like Hofstede, Schwartz recognizes France as having a unique blend of conservatism and intellectual and affective autonomy (roughly equivalent to high power-distance and strong individualism). Finally, he includes an element of environmental consciousness (relatively low for all countries with the client's sites) with his emphasis on harmony.

Summary of traditional measures of culture criteria: This review of culture theory highlights both the advantages and disadvantages of selecting sites for research on collaboration by using culture values alone. These values have strong impact. They do make it possible to hypothesize relationships to specific work behaviors and have been used widely in research. However, there is no one consistent set of variables, and many of the concepts were developed with data collected fifteen to thirty years ago. As a result, $\mathrm{AM}+\mathrm{A}$ suggested using these culture values in conjunction with other criteria, which seek to capture some of the changes taking place in corporate collaboration and technology-mediated teamwork.

\subsection{Criteria: Technological Innovation and Globalization}

The second set of criteria suggested for the client's study accommodates recent changes in the use of computer and communications technology and in global economics. There is a growing literature on the importance of recognizing generational differences, specifically, the rise of a generation of "digital natives," and the development of high growth cities and new forms of urban life.

As early as 1997, Johnston and Johal used culture theory to define the Internet as a new "virtual cultural region." Since then, the focus has shifted to the idea of digital nativity. Digital natives, or "millennials," have grown up surrounded by computers, mobile devices, video games, and the Internet. Older people have always used some other form of technology first; they are Digital Immigrants, held back by previous 
impressions of the "right" way to do things. Many claims have been made about the differences between digital natives and digital immigrants, such as the following quote by Prensky (2001) discussing changes in education: "Digital Natives are used to receiving information really fast. They like to parallel process and multi-task. They prefer their graphics before their text rather than the opposite. They prefer random access (like hypertext). They function best when networked. They thrive on instant gratification and frequent rewards. They prefer games to "serious" work....But Digital Immigrants typically have very little appreciation for these new skills that the Natives have acquired and perfected through years of interaction and practice."

To understand the full potential of new modes of communication, it is important to ask digital natives how they simultaneously work together and apart through social media. For the client to identify both current and future types of collaboration, sites with large numbers of new hires and digital natives should be visited. In the US, there has been some contention between digital natives and the baby boom generation; the baby boomers developed many of our traditional computer technologies but the new focus on social media often escapes them. They remain wedded to more structured media interactions, while digital natives thrive on instant availability and constant interaction. Outside the US, young Indian (and Chinese) college graduates have typically been the first to achieve computer literacy in their families. They join with fewer preconceptions about media and tend to see it in highly creative ways.

The rise of new types of cities is the second postmodern influence that the client should seek to capture in its study of collaboration. Throughout Asia, and parts of the Middle East, Latin America, and Africa, new cities are developing on the basis of new economic principles. In 1980, the estimated population of the United Arab Emirates was little more than 1 million; in 2009, it reached 5 million and, by the end of 2010 , the government expects an additional 1.9 million for a total of 7.5 million (UAE Interact, 2010). For every child born in the UAE in 2009, 22 migrants arrived, making the country the world leader in immigration. Thus, $73.9 \%$ of the working age population (15-64) consists of non-nationals with 2.74 men per woman. The median age of the UAE is 30.1 years: 32 for men and 34.7 for women (CIA, 2010). Singapore similarly has doubled its population from about 2.4 million in 1980 to almost 5 million in 2009, but its age and gender demographics are now less skewed (Statistics Singapore, 2010). Current population growth is about $1 \%$ per year, mainly through immigration $\left(15^{\text {th }}\right.$ in the world). The gender ratio is roughly equal, with a median age of 39 for both men and women (CIA, 2010), Both cities developed on the basis of trade, finance, and information rather than manufacturing, agriculture, or government.

Summary of technological innovation and globalization criteria: The client's professionals and staff currently working in such new cities are more likely to be globally diverse, young, digital natives who can anticipate future collaboration. Dubai currently epitomizes both the positive and negative effects of high growth and rapid urbanization. Investment in infrastructure has created a vibrant economy in the middle of the Gulf. However, gender ratios are highly skewed in favor of young men, and large numbers of expatriates are disconnected from traditional local culture. By contrast, Singapore followed a much more planned path to growth. Research there is likely to review more traditional Chinese attitudes to authority and collaboration. 


\subsection{Criteria: Equal Employment and Gender Ratio}

Part way through our analysis, the client made available demographic data that allowed us to analyze the number of digital natives at various company sites. This data also made it possible to investigate an additional criterion: gender ratio.

Hofstede notes that countries differ on a continuum of Masculinity and Femininity, which refer to traditional gender roles and to attitudes associated with each gender. Men in masculine societies seek out jobs that require mastery; women take jobs that require nurturing others. Furthermore, men are expected to be assertive; women, modest. By contrast, men and women in feminine countries are less subject to rigid gender expectations. Men may be elementary school teachers; women, computer programmers. Both genders tend to be modest, avoid direct conflict, and respect (and expect respect) from others. Two aspects of a balanced gender ratio are important for collaboration. First, feminine societies tend to focus more on participation, persuasion, and consensus than masculine societies. Unions are included in company management and techniques like participatory design are popular. Masculine societies focus more on challenge, reward, and individual recognition. Master programmers are celebrated and proffered as role models for new employees.

Summary of equal opportunity and gender ratio criteria: The US has been fighting for equal employment in technical positions for decades. For a while in the 1990s, the gender ratio in computer science improved, but stereotypes of technology and of those who work in technological jobs ("geeks") have reduced the number of women attracted to such positions. As a result, AM+A suggests Amsterdam as a site for study of collaboration in feminine cultures and Bangalore and/or Dubai as sites for the study of teamwork in young, masculine cultures. According to the employee demographic provided by the client, the gender ratio in Singapore is slightly higher than in the company's headquarter site or in Amsterdam. Nonetheless, we believe that the number of women in technical positions may well be higher in the Netherlands and is more likely to provide an opportunity to analyze egalitarian styles of work.

\subsection{Additional Considerations: Corporate Culture and the HQ Effect}

During client meetings, challenges of collaboration between headquarters staff and the client employees in other countries were mentioned. This reference opened a discussion about corporate culture and its relation to national culture. The client employees are made aware of the corporate values. Many of these values reflect a classically US emphasis on personal fulfillment (empowerment, fun), mastery (innovation), efficiency (frugality), and continuous improvement. Teamwork is critical, but the style of teamwork tends to be more masculine than feminine. The consensus was that the client's corporate values provide a backdrop to discussions within the company about collaboration and that differences in power between headquarters and the regions are just as much, or more, of an influence. 


\section{Conclusion}

This discussion presents AM+A's analysis of country cultures and specific cities, and their impact on values, attitudes, concepts, and behaviors related to teamwork. This analysis was used by the client to develop specific tools and techniques to improve collaboration, communication, and cooperation of multi-country teams.

\section{References}

1. Central Intelligence Agency. World Factbook (2010), http: / / www.cia.gov/library/publications / the-world-factbook/index.html (retrieved February 1, 2010)

2. Hofstede, G., Bond, M.: The Confucius connection: From cultural roots to economic growth. Organizational Dynamics 16, 417-433 (1988)

3. Hofstede, G.: Cultures and orgs.: Software of the mind. McGraw-Hill, N.Y. (1997)

4. Johnston, K., Johal, P.: The Internet as a "virtual cultual region": Are extant cultural classifications schemes appropriate? Internet Research: Electronic Networking Applications and Policy 9(3), 178-186 (1999)

5. Marcus, A., Baumgartner, V.-J.: A practical set of culture dimensions for global userinterface development. In: Masoodian, M., Jones, S., Rogers, B. (eds.) Proc. of CHI: 6th Asia Pacific Conf. APCHI 2004, pp. 252-261. Springer-Verlag, Heidelberg (2004), http: //springerlink. com

6. Markus, H.R., Kitayama, S.: Culture and the self: Implications for cognition, emotion, and motivation. Psychological Review 98, 224-253 (1991)

7. Prensky, M.: Digital natives, digital immigrants. On the Horizon 9(5), 1-6 (2001a), http: / /www . marcprensky.com/writing (retrieved February 1, 2010)

8. Prensky, M.: Digital natives, digital immigrants; Part II: Do they really think differently? On the Horizon, February 1, 2010. Retrieved from, vol. 9(6), pp. 1-9 (2001b), http: / / www . marcprensky.com/writing

9. Schwartz, S.H.: Beyond individualism/collectivism: New cultural dimensions of values. In: Kim, U., Triandis, H.C., Kagitcibasi, C., Choi, S.-C., Yoon, G. (eds.) Individualism and collectivism: Theory, method, and applications, pp. 85-119. Sage, Thousand Oaks (1994)

10. Schwartz, S.H.: A theory of cult. values and some implications for work. App. Psych: An Internat Review 48(1), 23-47 (1999) (retrieved February 1, 2010); EBSCO database

11. Triandis, H.C.: Collectivism vs. individualism: A reconceptualization of a basic concept in cross-cultural psychology. In: Verma, G.K., Bagley, C. (eds.) Cross-cult. studies of personality, attitudes, and cog., pp. 60-95. Macmillan, London (1988)

12. Triandis, H.C.: Culture and conflict. The Internat. Jour. of Psych., 35(2), 1435-1452 (2000); Reprinted Samovar, L.A., Porter, R.E., McDaniel, E.R. (eds.): Intercult. communication: A reader. Wadsworth Cengage, Boston (reprinted 2009)

13. Trompenaars, F., Hampden-Turner, C.: Riding the waves of culture: Understanding cultural diversity in global business, 2nd edn. McGraw-Hill, New York (1998)

14. Statistics Singapore (2010), http://www.singstat.gov.sg/stats/themes/people/hist/popn.html (retrieved February 1, 2010)

15. UAE Interact UAE population to rise in 2010 to 7.5 million (January 25, 2010), http: //uaeinteract. com/news (retrieved February 1, 2010) 